ISSN (print) 0867-2008 / ISSN (online) 2391-75 12

JULIUSZ RACZKOWSKI

Pracownia Architektury Wnętrz

Wydział Sztuk Pięknych

Uniwersytet Mikołaja Kopernika w Toruniu

ul. Sienkiewicza $30 / 32$

87-100 Toruń

Poland

jracz@umk.pl

\title{
MEDIEVAL MURALS RECENTLY UNCOVERED \\ IN THE CHAMBER ABOVE THE GATE OF THE CASTLE OF THE CHAPTER OF THE DIOCESE OF POMESANIA IN KWIDZYN. PRELIMINARY ANALYSIS: ICONOGRAPHY, STYLE, DATING AND FUNCTIONAL ROLE OF THE CHAMBER
}

\section{KEYWORDS}

Teutonic Order; Late Medieval Prussia; Kwidzyn/Marienwerder; Cathedral chapter in Kwidzyn/Marienwerder; medieval wall paintings; cathedral chancery in Kwidzyn/Marienwerder

The chamber above the gate of the castle of chapter of the diocese of Pome-
sania in Kwidzyn, is one of the few rooms (fig. I) in the castle which, de-
spite numerous renovations and changes of owners, preserved its original
architectural form, as well as layers of whitewashed plaster and paint. ${ }^{1}$ Medie-
val architectural elements of the chamber, including its Gothic stellar vault, are

I For summary of last, large scale renovation works see A. Dobry, XIX-wieczne prace restauratorskie w zespole zamkowo-katedralnym w Kwidzynie, Komunikaty Mazursko-Warmińskie I/203 (1994), pp. 35-42. 
mentioned in earlier, principal studies of the castle and cathedral compound in Kwidzyn. ${ }^{2}$

The presence of colourful murals decorating the vault of the chamber in question was first confirmed in October 1978, during studies conducted by the Muzeum Zamkowe w Malborku (Castle Museum in Malbork). During these works sample fragments of the historic plasters were uncovered and their stratigraphy analysed. 3 Additional studies were carried out in 1994 when presence of historic plasters, whitewash and polychromy (fig. 2-3), were confirmed on parts of the vault and upper sections of the walls of the chamber. ${ }^{4}$ During these studies, plans and guidelines for further conservation and restoration works, including removal of later layers, protection of uncovered polychromies and conducting 'preventive' conservation, were prepared. 5 The planned works began in the end of $20 \mathrm{I}$ a and beginning of $20 \mathrm{I} 2 .{ }^{6}$ The murals which were revealed at the time, however, were not studied in detail and it was only in the spring of 2017 that they were subject to comprehensive conservation and restoration works. ${ }^{7}$ Their main focus was, according to conservation commission, conducting preventive conservation and restoration of medieval arrangement of the chamber's interior (fig. 4). This included reconstruction of shelves in the niches in the chamber's walls, concealing post-medieval opening in the eastern wall and concealing and plastering over the i 9 th century. opening in the western wall.

2 R. Bergau, Schloss und Dom zu Marienwerder. Versuch einer kritisch-historischen Erlä̈terung, Zeitschrift für preußische Geschichte und Landeskunde 2 (1 865), pp. 605-630; M. Toeppen, Geschichte der Stadt Marienwerder und ihrer Kunstbauten, Marienwerder 1 875; Die Bau- und Kunstdenkmäler der Provinz Westpreussen, bearb. v. J. Heise, B. Schmid, Bd. 3: Pomesanien (Kreis Marienwereder östlich der Weichsel), Danzig I 898.

3 The study formed part of preparatory works for conducing further, large scale architectural and archaeological works in Kwidzyn castle. For details see A. Chrzanowicz, Badania architektoniczne. Zamek w Kwidzynie, t. I-3, PP PKZ Gdańsk 1977-1982, mps. Muzeum Zamkowe w Kwidzynie, sygn. 772, S. I, pp. 77-78.

4 T. Dembek, Dokumentacja konserwatorska prac badawczo odkrywkowych w kaplicy i gtównej klatce schodowej na zamku w Kwidzynie, Gdańsk 1994, mps. Muzeum Zamkowe w Kwidzynie, sygn. K/VII/ 10852 .

5 Ibid., p. 8.

6 The works were carried out by a private company "Zakład Usługowy Konserwacji Obiektów Zabytkowych Jan Wiśniewski” from Pruszcz Gdański. They lasted from December 20 I I to January 2012 and included the removal of secondary layers of plasters as well as protection of revealed mural decorations. Noteworthy discoveries included fragments of murals depicting figures as well as niches with pointed arches in the western wall.

7 These works were carried out by a team of specialists from the company "Zakład Usługowy Konserwacji Obiektów Zabytkowych Jan Wiśniewski” from Pruszcz Gdański. 


\section{Composition}

A decorative composition (fig. 5) covers the entire four-pointed stellar vault of the chamber's first bay (counting from the North). The polychormy is painted with tempera on lime whitewash. All panels of the vault were decorated; nine preserve more substantial remains, while on two of them only poorly visible traces remain. The ribs of the vault were first whitewashed and then painted red (their current look is the result of conservation).

The composition includes two elements which may not be integral in terms of chronology. The lower, narrowing parts of the panels are filled with red, s-shaped, floral ornaments. The wider sections above are decorated with depictions of individual figures - overall, two figures can be found adorning each point of the stellar vault. The northern outer panel is decorated with two figures, which suggests that similar arrangement originally could be found also in three other, outer sections of the vault. Figures are portrayed en plein pied (on the same level) in static poses, shown against a neutral, bright background. They are positioned under rounded, trefoil arcades which fill the space close to the gothic boss of the vault. ${ }^{8}$ Side sections of the decorated spaces are filled with rather rigid, floral ornament. Overall, the composition creates a very decorative impression: lower sections of red foliage and arches of arcades frame figures which seem to radiate around the vault's boss. Each figure is posed towards the center along the east-west axis (facing longer of the vault's ribs). The entire design clearly alludes to polychromy decoration of vaults of sacral spaces.

\section{ICONOGRAPHY}

The principal difficultly in the analysis of the artistic style and iconography of the uncovered murals is their poor preservation. Barely recognizable, individual attributes identify only a few of the figures, though all of them have haloes. In the outer panel, by the window, we can see St. James the Elder bearing pilgrim's attributes: he wears a flat hat with broad brim, there is an outline of a pilgrim's shell on his cloak and he holds a pilgrim's staff in his left hand. Alternatively, this figure may also depict St. Judoc whose attributes are similar to those of St. James, and whose cult was well established in Kwidzyn (fig. 6), which is attested by the fact that the first

8 The shape of the arcade is clearly visible in the depiction of St. John the Evangelist. 
known altar in Kwidzyn's cathedral, dating from I 363 , was dedicated to him. ${ }^{9}$ Opposite, on the same panel, is the figure of St. Dorothy holding a basket in her left hand. By the north-eastern point of the star one can recognize St. John the Evangelist, without a beard, with long bright hair and a chalice as his attribute. Identification of other figures is difficult and can only be hypothetical. One can presume that other male figures depict the Apostles. At least two of the depicted women are holy martyrs as they hold palms of martyrdom - one is located by the south-eastern point of the star (hence referred to as 'female saint with a palm leaf', fig. 7), second is located by the north-western point of the star (hence referred to as 'female saint with a raised palm leaf'). By the north-eastern point of the star there is a holy virgin with lose hair, wearing a diadem (hence referred to as 'female saint wearing a diadem'). The presence of St. Dorothy, who is rarely depicted alone, may indicate that the cycle included the traditional group of four holy virgins widely venerated in Prussia (St. Barbara, St. Catherine, St. Margaret and St. Dorothy). Since the female figure by the north-western point of the star wears sweeping surcot ouvert, perhaps she can be identified as St. Catherine who is often depicted wearing royal attire. Above her right hand there even seem to be some traces of an outline of a small wheel though identification of this feature is purely hypothetical. The rest of the figures are, unfortunately, impossible to identify.

Since the function of the chamber is unclear, it is not possible to suggest a hierarchy between the depicted saints. It is also not possible to identify the overall message conveyed by the composition because is not fully preserved and not all of its elements can be identified. For example, the murals do not seem to directly relate to Pomesanian liturgical calendar. The very presence of murals on a vault of one of castle's chambers is an expression of cult of saints that most likely was embedded in the liturgical customs of the monastic state of the Teutonic Order. The presence of St. John the Evangelist may be considered as a part of the cult of the patron saint of the cathedral and diocese although he was also venerated as part of the broader cult of saints and Apostles.

\section{STYLE}

The low level of preservation of the murals means that their chronology is not obvious. Lack of clearly visible signs of modelling and details suitable for dating, makes is difficult to date the composition on the basis of stylistic analysis. The con-

9 M. Glauert, Das Domkapitel von Pomesanien (1284-I527). (Prussia Sacra I), Toruń 2003, pp. 91-92. 
tours and underpainting layers of the images are what is mostly preserved. This means that we can interpret the general form and pose of the figures, the positioning of legs, and the flow of the fabrics, but we do not have a clear basis to determine the workshop from where the murals originated, nor to date them precisely. For this reason, any proposed interpretations have to be considered as hypotheses only.

In terms of technology, the whole compilation is uniform - which suggests that it was created at the same time. This interpretation is also supported by the form of the paintings. The figures of the saints are positioned in such a way that they are all facing the centre; because of this, some of the poses (when turned in the same direction) are repeated a number of times. For example, the holy virgins (the female saint holding a palm leaf, the female saint wearing a diadem, and St. Catherine) are all turned slightly to the right; their faces were probably painted in half-profile. The figures stand in a slightly hinted 'contrapposto' pose, with most of the weight of the body on the right foot, which makes the shoulders twist back slightly toward the supporting leg. The hand gestures are also repeated in a number of cases: for example the raised hand with the pointing finger turned upwards can be found on both the figure of St. John the Evangelist and St. James (or St. Judoc). Similarly, the bent arm of the female saint wearing the diadem is poised in the same way as that on the depiction that may portray St. Catherine. The way the drapery is arranged is also repeated in a number of places; for example, we can see a similar decorative knot on the shoulder of St. James (or St. Judoc), the female saint with a palm leaf, and St. Dorothy. Such similarities indicate that the analysed figures are integral to each other.

The composition of the mural, the way the figures are structured, the lines flowing towards the lower parts of the images, and the drapery, which is held up by wide festoons on both sides and falls gently in wavy cascades, all suggest that the murals were painted during the last quarter of the i 4 th century. The court mannerism features are also important for the dating of the mural. These are evident in the studied poses of the figures, especially in the case of the saint holding a palm leaf. The hand in which she holds the leaf is positioned far away from her body in a studied, artificial, gesture. We can see analogous forms of representation in Czech paintings from the last decades of the I 4 th century (for example works by the Master of the Trrebon Altarpiece). Some of the features of the attire of two of the female figures also help in establishing the dating of the mural. The martyr saint (female saint holding a palm leaf) is depicted wearing a narrow, close-fitting dress with tight sleeves which reach a little below the wrist. The neckline of the dress is quite deep and has a square cut. This sort of attire is of French origin and can also be seen in Central European iconography, where it was fashionable in the last quarter of the i 4 th century. The figure which has been (cautiously) identified 
as St. Catherine also wears clothing which helps determine the dating of the mural. She wears a closefitting underdress, with long, tight sleeves; over this she wears a 'surcot' with deeply slit sides which show much of the garment underneath (the so called 'corsette fendu'). The slits on the sides of the 'surcot' reach well beneath the hips, from where the heavy folds of the dress fall to the ground, and are rimmed with white patterns. This is a French version of courtly dress, often found in Western iconography from around the end of the I 4 th century. This type of garment is often portrayed to represent ceremonial dress or as an attribute of St. Catherine all throughout the i 5 th century.

A later dating of the mural (end of the 14 th century) is also suggested by the background of weaving floral motifs behind the figures. These have been best preserved by the north-west point of the star of the vault. The ornamental patterns are created on the basis of a single vine which is shaped into loose, semi-circular and wavy patterns.

However, the murals are also filled with strongly archaic forms. One example is the somewhat thickset look of some of the human figures, who are depicted with large heads, thick necks. Their stubby-fingered hands are also large and highly emphasized. Such proportions tend to characterise the male figures, but are also visible on the female saint with a raised palm leaf. She is portrayed differently than the other female saints from this cycle, all of whom are depicted with narrow shoulders, delicate arms and very small hands. The hairstyles, with deep, decorative hairlines forming at the level of the ears or lower, as seen on St. John the Evangelist, the female saint wearing a diadem, St. Dorothy and the female saint with a raised palm leaf, are characteristic of the painting traditions of the mid- 14 th century. ${ }^{10}$

The headdresses worn by the female figures are also archaic in style: for example the rigid 'chapel'-style headbands with a single fleuron over the forehead, worn low over the head. The pointed beard styles such as the one seen on St. James (or St. Judoc) are also archaic. All this perhaps suggests that the workshop which produced the murals was influenced significantly by local traditions.

The murals preserved in the Pomesanian cathedral are closest to which the murals from the so called 'chapel' can be compared. However, because they were completely re-painted as a result of a failed restoration attempt in the I 9 th centu$\mathrm{ry}^{11}$, they cannot serve as a good basis for an analysis of style (many of them could

Io For example in the depiction of the holy patrons of the church on the east wall of the church of St. John the Baptist and St. John the Evangelist in Torun (Germ. Thorn); the figures of the apostles in the church of St. Thomas in the Nowe Miasto Lubawskie (Germ. Neumark); the figures of the apostles in the chapel of the Grand Master in Malbork (Germ. Marienburg) etc.

II The Protestants covered the murals with whitewash in the I 6th century. They were discovered on the 25 July I 862 , during the dismantling of the Protestant wooden gallery which ran along 
perhaps be said to lack a specific style altogether). The remains of the original decoration of the upper choir from the end of the I 4 th century, on the other hand, are very faint and difficult to interpret. ${ }^{12}$ Like the paintings on the vaults, they have only been preserved in the underpainting layer. Only the general composition can be treated as a basis for comparisons. It is in this context that it is worth noticing the recurring motif of a female figure in three quarter view, with her arm positioned far from her chest and pointing downwards; this type of depiction can be seen on the portrayal of the foolish virgins on the north wall and of St. Mary Magdalene on the southern wall of the cathedral and it resembles the depiction of the female saint with a palm leaf. Another characteristic feature of figures depicted in the so called 'chapel' is the drapery, which falls in voluminous cascades from one shoulder (female saint with a palm leaf, female saint wearing a diadem) in a manner that can also be observed on the southern wall of the altar composition (depictions of St. Dorothy and St. Ursula).

Given the scale and variety of the decorations ${ }^{13}$, created in the naves as well as the upper choir since the I 370 's, it seem justifiable to assume that one of the artistic workshops working in the cathedral was also commissioned to create murals in the castle. A more specific identification is highly unlikely however. The murals were probably made during the time of Bishop Johannes I Mönch, who was also responsible for the decorating of the cathedral in Kwidzyn (Germ. Marienwerder).

\section{THE FUNCTION OF THE CHAMBER}

The chamber where the murals were uncovered is located precisely above the entrance gate, and is connected to the cloister. The chamber has two bays, it is locat-

the side naves of the church. Following the decision of von Quast and Stüler, the whitewash covering the paintings was removed, and a Westphalian artist, Fishbach, was commissioned to restore the paintings. After his death in 1862 the restoration works were continued by a less skilled, local painter, Prahl jun. His flat, 'contour' re-paintings were partly removed in $193 \mathrm{I}-$ - 1934 by Artur Fahlberg, whose own work on the murals, despite being stylised in a Gothic manner, did not restor the original look of the images. See Dobry (as n. I).

12 See: J. Raczkowski, Problematyka konserwatorska malowidet ściennych górnego chóru katedry w Kwidzynie, in: Studenci o konserwacji, t. 3, ed. T. Korzeniowski, Toruń 200 I, pp. 156-164; idem, Malowidta ścienne w katedrze w Kwidzynie (catalogue headword), in: Fundacje artystyczne na trenie państwa krzyżackiego w Prusach. Katalog wystawy w Muzeum Zamkowym w Malborku, t. I, ed. B. Pospieszna, Malbork 2010, II.3.2., p. I67.

13 The lack of uniformity of the cycle is indicated by the variety in types of compositions, non-uniform themes, and repetitive appearances of some of the saints. The murals were created in the last part of the i 4 th century. 
ed on the first floor of the north wing of the castle, and has been usually identified as a chapel in contemporary literature. ${ }^{14}$ However, observations regarding the very structure of this space suggests otherwise. The chamber is not oriented, no traces of the location of the altar have been preserved and the surviving plaster bears no marks of medieval consecration crosses. The presence of a chapel in the castle is also not supported by historical sources ${ }^{15}$ (there is no mention of any altar or chapel located in the castle). ${ }^{16}$ Mario Glauert argues that the close proximity of the cathedral meant that a separate sacral space within the castle was not necessary. ${ }^{17}$ It is well worth remembering that in the middle ages two altars functioned in the oratory of the canons in the upper choir of the cathedral, which was a place designated for communal celebration of divine office. ${ }^{18}$

Nonetheless, the shape of the interior, covered by a gothic stellar vault and bearing elaborate decorations of a sacral character, suggests that this small space served some specific function. That it's function was in some sense special or particular is indicated by the fact that it contains three large niches with pointed arches in the western wall ${ }^{19}$, and has a heating system (the heating duct is located in the north-east corner). ${ }^{20}$ These sort of features are usually found in living chambers,

14 M. Haftka, Zamek w Kwidzynie. Przewodnik, Malbork 1983, pp. 43, 60; idem, Zamki krzyżackie w Polsce. Szkice z dziejów, Malbork I999, p. I46; L. Krantz-Domasłowska, Katedra $w$ Kwidzynie, Torun 1999 , pp. 25, 52. She argues that the chapel could not have served a representational role because of its small size.

is In accordance to the Teutonic Order's rule, which the Pomesanian chapter followed, a castle had to include a dormitory, a chapterhouse, and a refectory. Mario Glauert compiled a collection of all mentions of specific rooms in the castle found in the sources, for example the winter refectory, the summer refectory, chapterhouse, dormitory (divided up into cells), see Glauert (as n. 9), pp. 107-1 10.

16 The castle chapel in Prabuty (Germ. Riesenburg), for example, is mentioned separately. Two of its chaplaincies were trasferred to the choit of the cathedral, see Codex Diplomaticus Prussicus. Urkunden-Sammlung zur ältern Geschichte Preusens aus dem Königl. Geheimen Archiv zu Königsberg nebst Regesten, ed. J. Voigt, Bd. IV, Königsberg I 853 , n. 67, p. 9 I.

${ }_{17}$ Glauert (as n. 9), p. 108.

18 See the document signed by bishop John Mönch in 1389: Codex Diplomaticus Prussicus (as n. 16), p. 9 I-94; Krantz-Domasłowska (as n. I 4), p. 55.

19 The fourth of the wall niches is has been constructed later, in place of a i 9 th century doorway. In two of the original, medieval niches, grooves for the shelves have been preserved. On the basis of earlier archaeological and architectural research, Łukasz Stawski claims that the discussed chamber originally had four, large, deep niches with pointed arches located in the western wall. See Ł. Stawski, Pomieszczenie nad przejazdem bramnym zamku kapituty pomezańskiej w Kwidzynie. Przemiany architektoniczno-funkcjonalne, Kwidzyn 20 I 3, mps. Muzeum Zamkowe w Kwidzynie, p. 8.

20 This was a rare type of heating system during the middle ages. The heating duct carried the heat from a furnace located on the ground floor of the east part of the castle. 
however the canons did not possess separate living quarters. The chapter's provost was the only cleric who, despite the adopted rule, did not live together with the other brethren. While the sources do indicate the presence of the provost's curia $^{21}$, its location is not specified clearly ${ }^{22}$. What we do know is that since the i 5 th century, the provost lived in Szymbark (Germ. Schönberg) ${ }^{23}$, Mario Glauter suggests that before this time, the provost's curia was located beyond the castle walls. ${ }^{24}$

The chamber could have played the role of a chancellery (in the sources there is mention of the presence of Brifkammer/Brieflade within the castle). ${ }^{25}$ The localization of the chancellery, as well as the bishop's archive and of the library, is unknown. The wall niches with pointed arches seem to be well suited to the storing of documents, medieval writing materials, documents and volumes. The chamber is well lit - it had a large window (its current shape, size and structure are secondary reconstructions). The heating system would have allowed work to be carried out all year round.

At the turn of the i 4 th century, during the time of bishops Johannes I Mönch and Johannes II Ryman, the amount of written material produced by the chapter increased significantly. ${ }^{26}$ It was here that documents and legal acts $^{27}$ as well as chronicles $^{28}$, chapter's annals ${ }^{29}$, theological works ${ }^{30}$ and writings connected with

${ }_{21}$ The document from 1363 r. was issued loco cathedralis Pomesaninsis in domo domini prepositi, see Glauert (as n. 9.), p. 245.

22 Ibid., p. 108.

23 Glauert (as n. 9), p. 245; A. Radzimiński, Kwidzyn w średniowieczu, in: Kwidzyn. Dzieje miasta, ed. K. Mikulski, J. Liguz, Kwidzyn 20 I 3, p. 77.

24 Glauert (as n. 9), p. 245; also Radzimiński (as n. 23), p. 77.

25 Glauert (as n. 9), p. I 6.

26 Radzimiński (as n. 23), pp. 79-80.

27 In the 14 th century the castle was the place of issuing documents for the curia and for the bishop for example the document issued by Johannes I Mönch, which has already been mentioned, and which bore the adnotation: Datum et actum in castro nostro Marienwerder, see Codex Diplomaticus Prussicus (as n. I 6), p. 94. Records of the precise place of issuing of the documentation concern earlier periods. We do know that din the middle of the I 4 th century, the bishop of Pomezania issued two documents (1 345, 1 349) in the castle refectory. See Glauert, (as n. 9), p. 107.

28 Johanns von Posilge, Officials von Pomesanien Chronik des Landes Preussen (von 1360 an, forgesetzt bis I4I9), ed. E. Strehlke, Scriptores rerum Prussicarum, vol. III, Leipzig I 866, pp. 13-388.

29 Johannis Marienwerder, Pomesaniensis decani, Annales capituli Pomesaniensis 1391-1398, ed. M. Toeppen, Scriptores rerum Prussicarum, vol. V, Leipzig I 874, pp. 430-434.

30 Most were written by Johannes Marienverder. See M. Borzyszkowski, Problematyka filozoficzna i teologiczna w twórczości Jana z Kwidzyna (I343-I417), Studia Warmińskie 5 (I 968), pp. I I I- I99; idem, Problematyka filozoficzna i teologiczna w twórczości Jana z Kwidzyna (1343-1417). Dokończenie, Studia Warmińskie 6 (1969), pp. 85-1 7 1; idem, Komentarz do Prologu „Expositio Symboli Apostolorum" Jana z Kwidzyna, in: Materiaty do historii teologii średniowiecznej 
the canonization process of Dorothy of Montau ${ }^{31}$ were all compiled. A place providing conditions for the creation of such a rich written output must have existed within the castle. The sacral nature of the murals decorating the vault of the analysed chamber would also be fitting for a space used by Pomesanian canons.

\section{Edited Sources And Literature}

Hipler, Franz., ed. "Das Leben der seligen Dorothea von Preussen. Nach der deutschen Lebensbeschreibung des Johannes Marienwerders in neuerer Schriftsprache." Zeitschrift für die Geschichte und Alterstumskunde Ermlands 10 (1 894): 297-504.

Hipler, Franz., ed. Septililium Beatae Dorotheae Montovensis auctore Joanne Marienwerder. (Annalecta Bollandiana 2-4). Bruxelles: I 883- I 885 .

Strehlke, Ernst., ed. "Johanns von Posilge, Officials von Pomesanien, Chronik des Landes Preussen (von 1360 an, fortgesetzt bis 1419) zugleich mit des auf Preussen bezuglichen Abschnitten aus der Chronik Detmar's von Lübeck." In Scriptores Rerum Prussicarum. Die Geschichtsquellen der preussischer Vorzeit bis zum Untergange der Ordensherrschaft. vol. 3, i 3-399. Leipzig: Verlag von S. Hirzel, i 866.

Toeppen, Max., ed. "Johannis Marienwerder, Pomesaniensis decani, Annales capituli Pomesaniensis I391-1398." In Scriptores rerum Prussicarum. Die Geschichtsquellen der preussischer Vorzeit bis zum Untergange der Ordensherrschaft. vol. 5, 430-434. Leipzig: Verlag von S. Hirzel, i 874.

Triller, Anneliese., Borchert, Ernst., eds., with Hans Westpfahl. Liber de festis Magistri Johannes Marienwerder. Offenbarungen der Dorothea von Montau. (Forschungen und Quellen zur Kirchen- und Kulturgeschichte Ostdeutschlands 25). Köln, Weimar, Wien: Böhlau Verlag, 1992.

$w$ Polsce, vol. 2 (Textus et studia. Historiam theologiae in Polonia excultae spectantia II/2), Warszawa i 974, pp. 39-6i.

${ }_{31}$ All of the texts related with St. Dorothy of Montau were written by Johaness Marienverder. See for example list of her revelations: Liber de festis (edition: Liber de festis Magistri Johannes Marienwerder. Offenbarungen der Dorothea von Montau, ed. A. Triller, E. Borchert, nach Vorarbeiten v. H. Westpfahl (Forschungen und Quellen zur Kirchen- und Kulturgeschichte Ostdeutschlands 25), Köln-Weimar-Wien 1992); mystic treatise Septililium (edition: Septililium Beatae Dorotheae Montovensis auctore Joanne Marienwerder, opera et studio Francisci Hipler (Annalecta Bollandiana 2-4), Bruxelles i 883-1885); Life of St. Dorothy in Latin and German (editions: Das Leben der seligen Dorothea von Preussen. Nach der deutschen Lebensbeschreibung des Johannes Marienwerders in neuerer Schriftsprache, ed. F. Hipler, Zeitschrift für die Geschichte und Alterstumskunde Ermlands Io (1894), pp. 297-504; Vita Dorotheae Montoviensis Magistri Johannis Marienwerder, ed. H. Westpfahl, A. Triller (Forschungen und Quellen zur Kirchen- und Kulturgeschichte Ostdeutschlands I), Köln-Graz I 964 ). 
Voigt, Johannes., ed. Codex Diplomaticus Prussicus. Urkunden-Sammlung zur ältern Geschichte Preusens aus dem Königl. Geheimen Archiv zu Königsberg nebst Regesten. Vol. IV. Königsberg: Gebrüdern Vornträger, I 853.

Westphal, Hans., Triller, Anneliese., eds. Vita Dorotheae Montoviensis Magistri Johannis Marienwerder. (Forschungen und Quellen zur Kirchen- und Kulturgeschichte Ostdeutschlands i ). Köln, Graz: Böhlau Verlag, i 964.

Bergau, Rudolf. "Schloss und Dom zu Marienwerder. Versuch einer kritisch-historischen Erläuterung." Zeitschrift für preußische Geschichte und Landeskunde 2 (I 865): 605-630 .

Borzyszkowski, Marian “Komentarz do Prologu „Expositio Symboli Apostolorum” Jana z Kwidzyna." In Materiaty do historii teologii średniowiecznej w Polsce, vol. 2 (Textus et studia. Historiam theologiae in Polonia excultae spectantia II/2), 39-6I. Warszawa: Wydawnictwo Akademii Teologii Katolickiej, I 974.

Borzyszkowski, Marian. "Problematyka filozoficzna i teologiczna w twórczości Jana z Kwidzyna ( I 343- I 4 I 7)." Studia Warmińskie s ( I 968): I I I- I 99.

Borzyszkowski, Marian. "Problematyka filozoficzna i teologiczna w twórczości Jana z Kwidzyna (I 343-I 4 I 7). Dokończenie.” Studia Warmińskie 6 ( I 969): 85-I 7 I.

Chrzanowicz, A. Badania architektoniczne. Zamek w Kwidzynie. Vol. I-3. PP PKZ Gdańsk 1977-1982. Ms. Muzeum Zamkowe w Kwidzynie, sygn. 772.

Dembek, T. Dokumentacja konserwatorska prac badawczo odkrywkowych w kaplicy i gtównej klatce schodowej na zamku w Kwidzynie. Gdańsk I 994. Ms. Muzeum Zamkowe w Kwidzynie, sygn. K/VII/ 10852.

Dobry, Artur. "XIX-wieczne prace restauratorskie w zespole zamkowo-katedralnym w Kwidzynie." Komunikaty Mazursko-Warmińskie I/203 (1 994): 35-42.

Glauert, Mario. Das Domkapitel von Pomesanien (I284-I527). (Prussia Sacra I). Toruń: Wydawnictwo Naukowe UMK, 2003.

Haftka, Mieczysław. Zamek w Kwidzynie. Przewodnik. Malbork: Muzeum Zamkowe, I 983 .

Haftka, Mieczysław. Zamki krzyżackie w Polsce. Szkice z dziejów. Płock: Wydawnictwo Consort, Malbork: Muzeum Zamkowe, I 999.

Johannes Heise, Bernhard Schmid, edit. Die Bau- und Kunstdenkmäler der Provinz Westpreussen. Vol. 3: Pomesanien (Kreis Marienwereder östlich der Weichsel). Danzig: Kommissions-Verlag von Th. Bertling, i 898.

Krantz-Domasłowska, Liliana. Katedra w Kwidzynie. Toruń: Wydawnictwo Naukowe UMK, I 999.

Raczkowski, Juliusz. "Malowidła ścienne w katedrze w Kwidzynie.” (catalogue headword II.3.2.) In Fundacje artystyczne na trenie państwa krzyżackiego w Prusach. Katalog wystawy w Muzeum Zamkowym w Malborku, vol. I, edited by Barbara Pospieszna, I 67. Malbork: Muzeum Zamkowe, 20 г 0. 
Raczkowski, Juliusz. "Problematyka konserwatorska malowideł ściennych górnego chóru katedry w Kwidzynie." In Studenci o konserwacji, vol. 3, edited by Tomasz Korzeniowski, I 56-164. Toruń: Wydawnictwo Naukowe UMK, 200 I.

Radzimiński, Andrzej. "Kwidzyn w średniowieczu." In Kwidzyn. Dzieje miasta, edited by Krzysztof Mikulski, Justyna Liguz, 55-90. Kwidzyn: Kwidzyńskie Centrum Kultury, 2013.

Stawski, Ł. Pomieszczenie nad przejazdem bramnym zamku kapituty pomezańskiej w Kwidzynie. Przemiany architektoniczno-funkcjonalne. Kwidzyn 20 I 3. Ms. Muzeum Zamkowe w Kwidzynie.

Toeppen, Max. Geschichte der Stadt Marienwerder und ibrer Kunstbauten. Marienwerder: Kanter, I 875.

ABstract

Medieval murals recently uncovered in the chamber above the gate of the castle of the chapter of the diocese of Pomesania in Kwidzyn. Preliminary analysis: iconography, style, dating and functional role of the chamber

Medieval murals recently uncovered in the chamber above the gate of the castle of the chapter of the diocese of Pomesania in Kwidzyn. Preliminary analysis: iconography, style, historical costume elements, dating, briefly functional role of the chamber and written in the Pomesania Chapter of the last quarter of the 14th century and early 15 th century. 
[299]

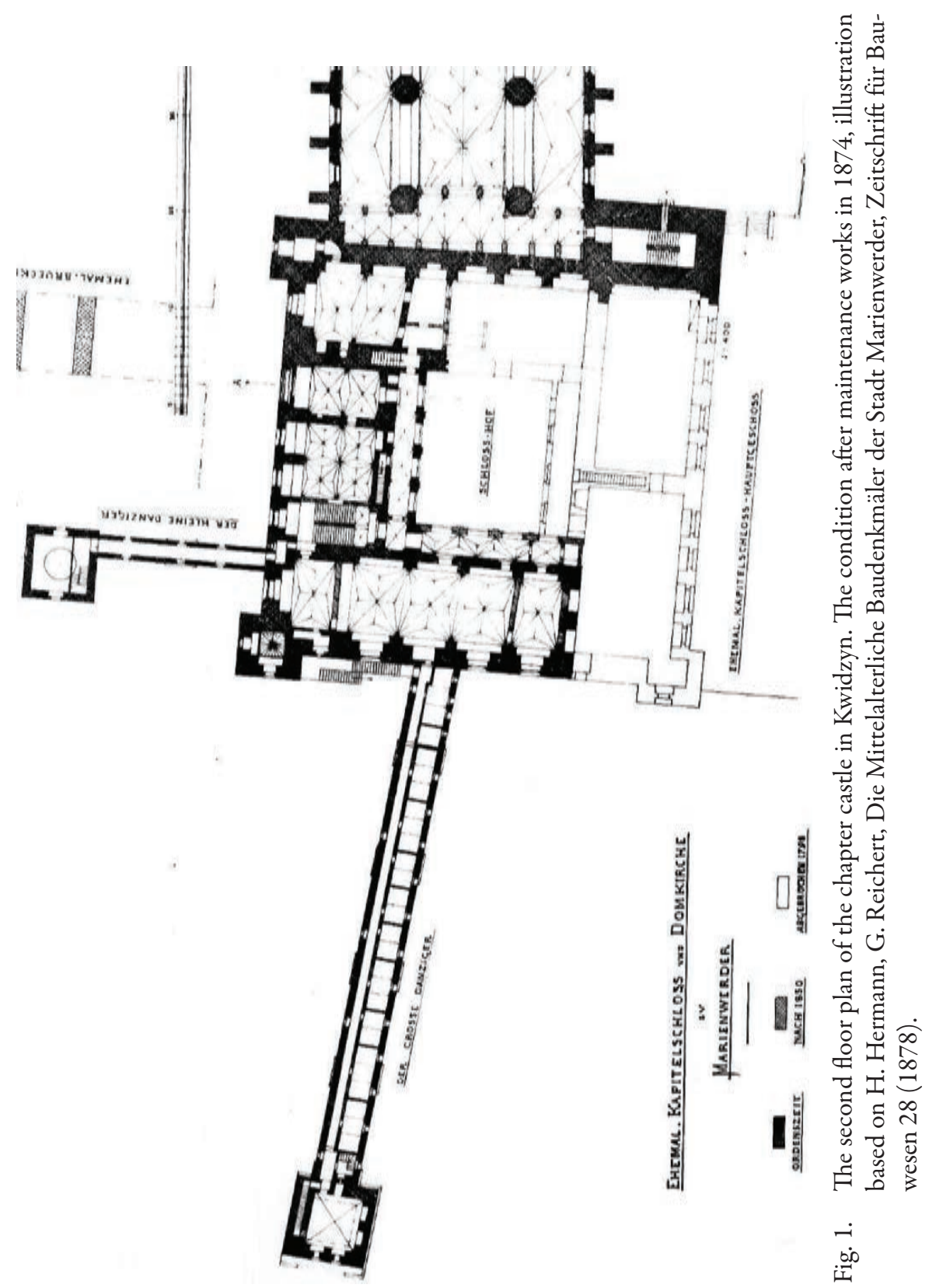


[300]
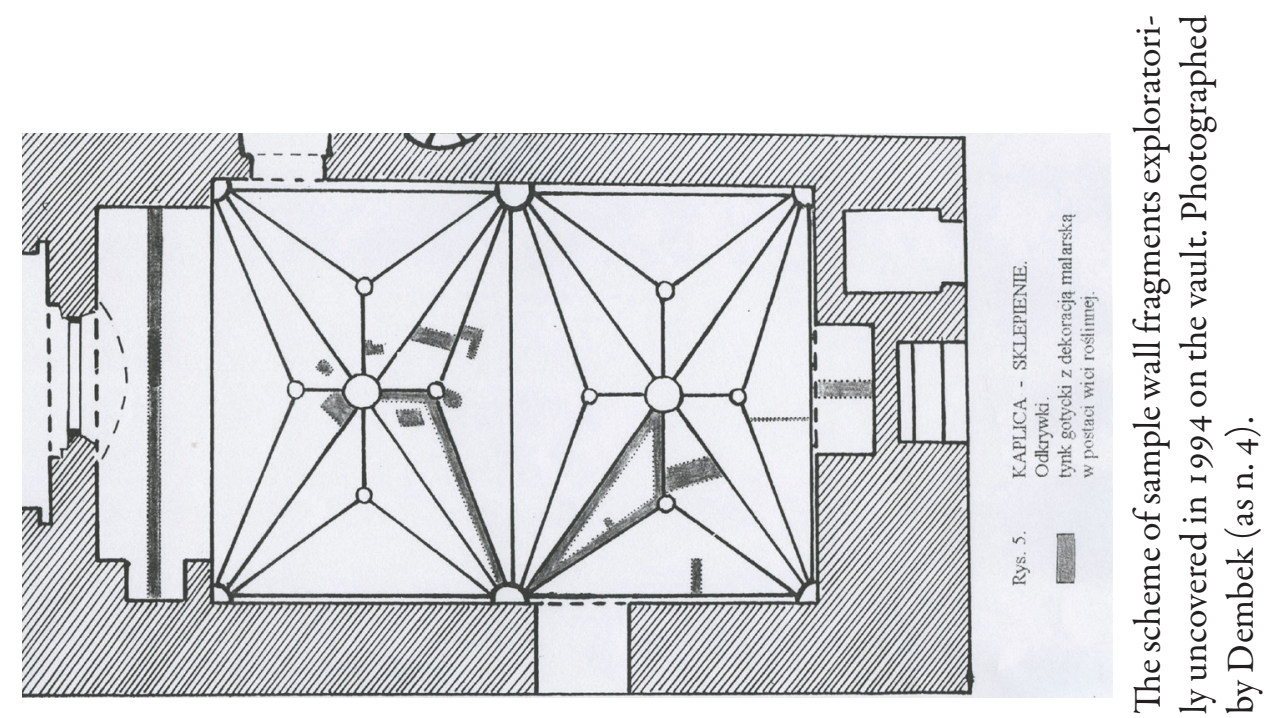

$\dot{n}$
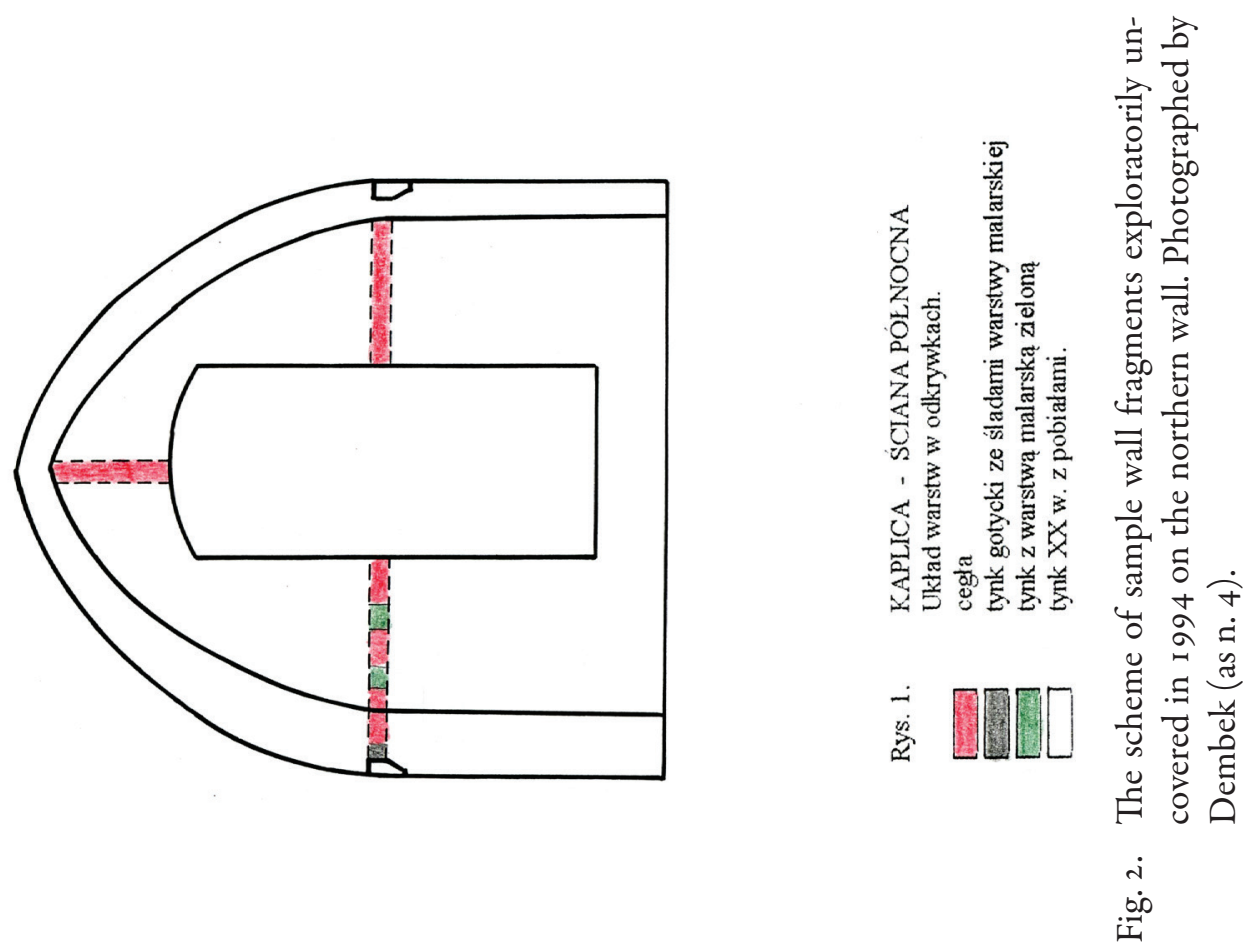


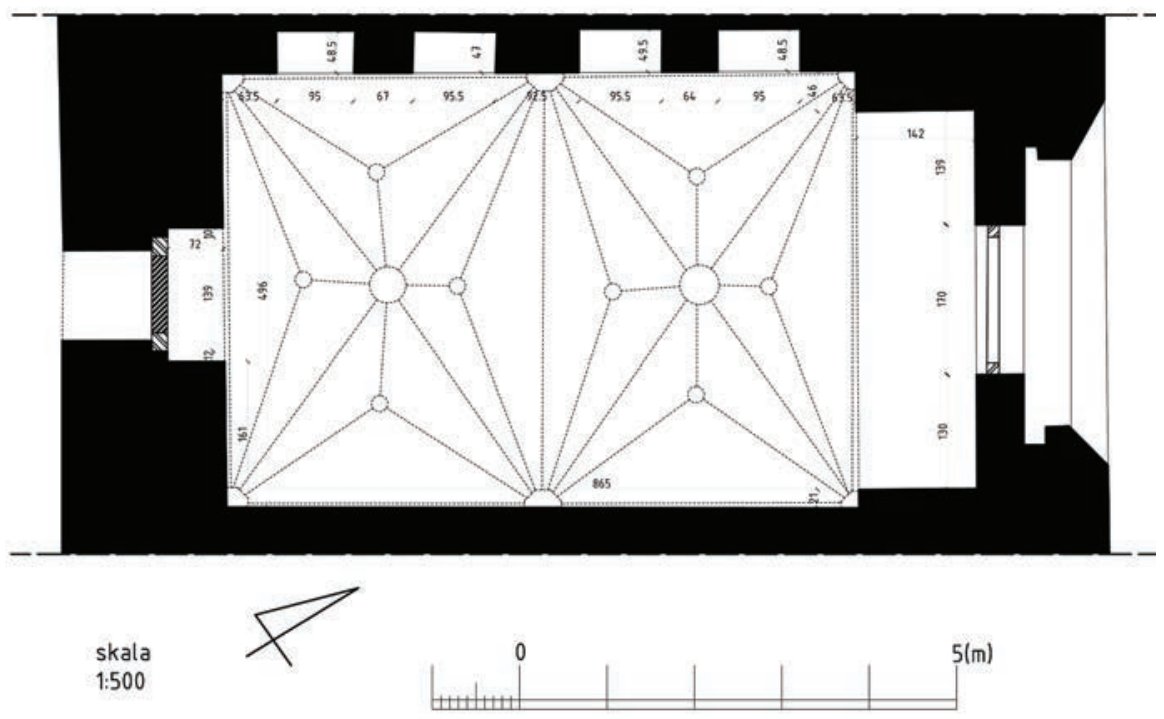

Fig. 4. Room plan after maintenance works in 2017 . Unveiling of all cabinet niches in the Western wall and restoring of medieval appearance of the interior, ed. by J. Raczkowski, illustrated by Tomasz Kowalski.

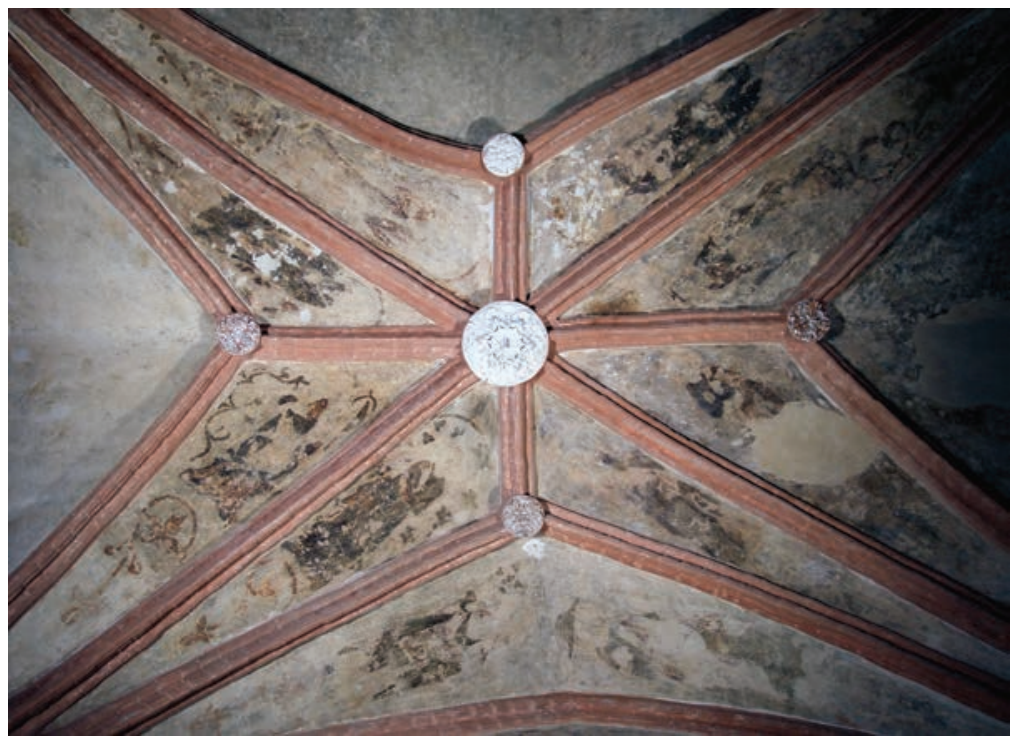

Fig. 5. Starry vault with uncovered murals, the condition after maintenance works, June 2017, photographed by J. Raczkowski. 
[302]

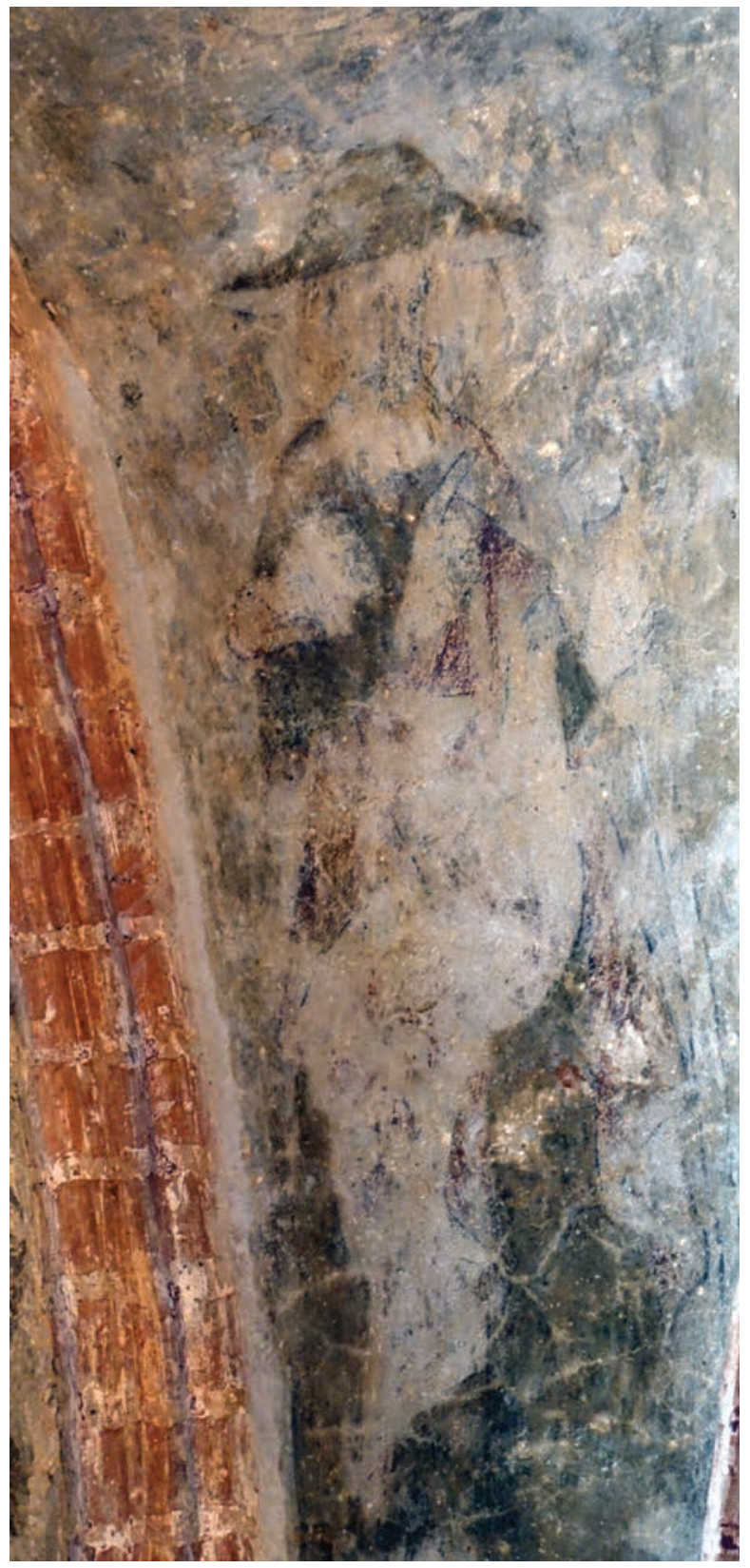

Fig. 6. The depiction of St. Jacob/Jodok (?), the condition after maintenance works, June 2017 , photographed by J. Raczkowski. 


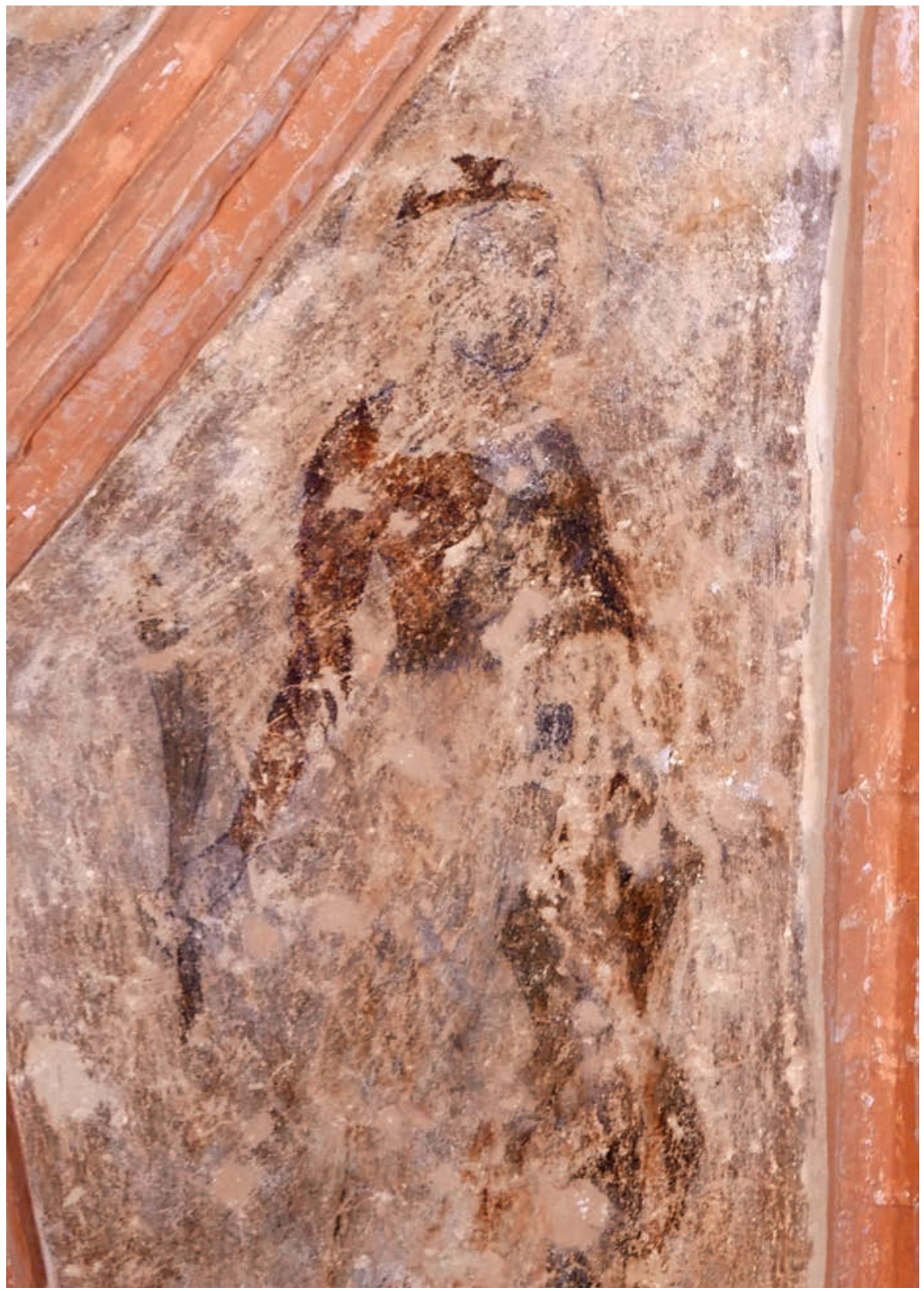

Fig. 7. The depiction of the unrecognized Holy Virgin with the palm of martyrdom, a symbol of victory, the condition after maintenance works, June 2017 , photographed by J. Raczkowski. 